\title{
Fonksiyonel Gıda Bileşenlerinin Tespit Edilmesinde Enstrümental Analiz Tekniklerinin Önemi
}

\author{
Pınar Ankaralıgil ${ }^{1,2}$, Buket Aydeniz-Güneşer ${ }^{2 *}$ \\ ${ }^{1}$ Uşak İl Tarım ve Orman Müdürlüğü, Gıda ve Yem Şubesi, Uşak, Türkiye, (ORCID: 0000-0001-6377-5303), pinar.ankaraligil@gmail.com \\ ${ }^{2 *}$ Uşak Üniversitesi, Mühendislik Fakültesi, Gıda Mühendisliği Bölümü, Uşak, Türkiye (ORCID: 0000-0003-2197-5504), buket.guneser@usak.edu.tr
}

(1st International Conference on Applied Engineering and Natural Sciences ICAENS 2021, November 1-3, 2021)

(DOI: 10.31590 /ejosat.995395)

ATIF/REFERENCE: Ankaralıgil, P. \& Aydeniz-Güneşer, B. (2021). Fonksiyonel Gıda Bileşenlerinin Tespit Edilmesinde Enstrümental Analiz Tekniklerinin Önemi. Avrupa Bilim ve Teknoloji Dergisi, (28), 251-258.

\section{Öz}

Fonksiyonel gida terimi, vücudumuzun ihtiyaç duyduğu temel besin öğelerine ilave olarak tüketildiğinde bedensel ve zihinsel sağllğa olumlu etkilerinin olduğu bilimsel olarak kanıtlanan öğeleri de içeren gıdaları ifade etmektedir. Günümüzde, salgınların giderek artması ve günlük diyetimizde tercih ettiğimiz besinlerin bütüncül sağlık durumunu etkilemesi nedeniyle, fonksiyonel bileşenleri içeren yenilebilir veya içilebilir tüm ürünlerin tüketimine olan talep artmaya devam etmektedir. Bununla birlikte, fonksiyonel ürünlerin farklı yaştaki tüketiciler için uygun olmayabileceği ve bazı olası hastalıkların fonksiyonel bileşenler tarafından tetiklenebileceği de unutulmamalıdır.

$\mathrm{Bu}$ derleme çalışmasında, fonksiyonel gıda bileşenlerin tespit edilmesinde kullanılan enstrümental analiz teknikleri üzerinde durulmuştur. Spektroskopi, kromatografi, kütle spektrometresi ve ayrıca kombine tekniklerin gıdalardaki fonksiyonel bileşenlerin tespitinde en çok kullanılan enstrümental analiz teknikleri olduğu sonucuna varılmıştır.

Anahtar Kelimeler: Fonksiyonel gıda, Enstrümental analiz, Spektroskopi, Kromatografi, Kütle spektrometresi.

\section{The Importance of Instrumental Analysis Techniques in the Determination of Functional Food Components}

\begin{abstract}
Functional food defined as foods contained that have been scientifically proven to their positive effects on physical and mental health, beyond adequate essential nutrients the our body needs. Nowadays, consumer demand for all edible or drinkable products containing functional ingredients continues to increase due to the increasig epidemics and the importance of a holistic health approach.

In addition, it should be kept in mind that all functional products may not be suitable for consumers of different age groups, and some possible diseases may be triggered by functional ingredients.

This review study focused on the instrumental analysis techniques used in identification of functional food components It was concluded that spectroscopy, chromatography, mass spectrometry and also combined/hybrid techniques are the most used instrumental analysis techniques in the detection of functional components in foods.
\end{abstract}

Keywords: Functional food, Instrumental analysis, Spectroscopy, Chromatography, Mass spectrometry.

\footnotetext{
* Sorumlu Yazar: buket.guneser@usak.edu.tr
} 


\section{Giriş}

FFC (Functional Food Center - Fonksiyonel Gida Merkezi) fonksiyonel gıdaları; toksik olmayan miktarlarda tüketildiğinde mevcut sağlık durumunun iyileştirilmesinde, kronik hastalık veya semptomların önlenmesinde veya tedavisinde etkili olduğu ve bir sağlık yararı sağladığı klinik olarak kanıtlanmış ve belgelenmiş, biyolojik aktif bileşikleri içeren doğal veya işlenmiş gıdalar" olarak tanımlamaktadır (FFC, 2020). Fonksiyonel gida bileşenleri; kanser, diyabet, hipertansiyon ve kalp hastalıklarının önlenmesi ve ayrıca; osteoporoz, anormal bağırsak fonksiyonu ve artrit rahatsızlıklarının hafifletilmesi ile ilişkilendirilmektedir (Bruulsema, 2000). Sağlıkla ilgili tüketici endişelerinin giderek artması ve diyet-sağlık ilişkisinin çarpıcı bilimsel bulgularla ortaya koyulması nedeniyle fonksiyonel gıdalar büyük ilgi görmektedir (Siegrist ve ark., 2015; Hara ve ark., 2018).

Bununla birlikte; işlenmemiş bir gıdadaki bileşenlerin miktarını kontrol edebilmek gerek üretici gerekse tüketici için arzu edilen bir gereksinimdir. Meyve ve sebzelerdeki fonksiyonel bileşenlerin içeriği; ürünün olgunluğuna, çeşidine ve üretim prosesine bağlıdır (Hara vd., 2018). Hayvansal gidalarda ise bu bileşenlerin içeriği hayvanın beslenmesine, cinsiyetine ve yaşa bağlı olarak değişebilmektedir. Tüketiciler açısından gıda kalite ve güvenliğinin sağlanması için gıdalarda mevcut bileşenlerin, kalıntıların ve kontaminantların saptanması gereklidir.

Gıda ürünleri; vitamin, şeker, protein, lipit, lif, aroma, renk pigmentleri, antioksidan, mineral ve diğer organik bileşikler olmak üzere çeşitli kompleks yapılardan oluşmaktadır (Otles ve Ozyurt, 2015). Gıda içindeki moleküler yapı ve moleküller arası etkileşimlerle yönetilen bu bileşenlerin fonksiyonel özellikleri ve mevcut miktarları gıda ürünlerinin özelliklerini oluşturur (Nawrocka ve Lamorska, 2013).

Hızlı sonuç vermeleri, kişisel hataların ortadan kaldırılmasına olanak sağlamaları ve analitik duyarlılıklarının yüksek olması gibi avantajlara sahip olan enstrümental analiz teknikleri, gıda formülasyonlarının karakterizasyonu için yaygın olarak kullanılan ve özel yazılımlar tarafından kontrolü sağlanan, farklı çalışma prensiplerine sahip birçok ölçüm metodunu içermektedir. $\mathrm{Bu}$ tekniğin içerisinde; spektroskopik, kromatografik, termal ve elektrokimyasal analiz yöntemleri yer almaktadır. Kullanılacak en uygun enstrümental tekniğin belirlenmesi; analiz edilecek örneğin fiziko-kimyasal özelliklerine, analiz edilecek maddenin tespit limitine ve kromatografik çözünürlüğüne bağlı olarak değişebilmektedir (Deepak, 2015; Otles ve Ozyurt, 2015).

$\mathrm{Bu}$ çalışmada; fonksiyonel gida bileşenlerinin tespit edilmesinde en çok kullanılan spektroskopik, kromatografik ve kütle spektrometresi teknikleri üzerinde durulmuştur.

\section{Fonksiyonel Gıda Bileşenleri}

Potansiyel yararlılığı bulunan fonksiyonel bileşenler, gıda formülasyonu içerisinde natürel olarak yer alabildiği gibi, tamamen dışarıdan ilave ya da mevcut bileşeni zenginleştirme yöntemleriyle de formülasyona eklenebilmektedir. Fonksiyonel bileşenler kategorisinin en yaygın bilinen üyeleri arasında karotenoidler, diyet lifi, yağ asitleri, flavonoidler, izotiyosiyanatlar, fenolik asitler, prebiyotikler, probiyotikler ve fitoöstrojenler yer almaktadır (Guiné ve ark., 2009).
Karotenoidler: Doğal fonksiyonel bileşenlerden biri olan karotenoidler sarıdan kırmızıya kadar değişen geniş bir renk aralığından sorumlu olan tetraterpenlerdir [Acton, 2013]. Havuç, sspanak, brokoli, marul, bezelye, tere, domates, portakal, mandalina, mısır, kırmızı biber, kayısı, mango, papaya, kavun ve tatlı patates gibi gıdaların karakteristik renk ve fonksiyonel özelliklerinde, karotenoidlerin rolü baskın biçimde gözlenir (Southon ve Faulks, 2003).

Piyasada mevcut olan karotenoid bazlı besin takviyelerinin kemik sağlığını iyileştirme, yaşlanmayı geciktirme, sporcu beslenmesini destekleme (fiziksel dayanıklılığ 1 arttırma), görmeyi iyileştirme, kardiyovasküler ve gastrointestinal sistemleri korumaya yönelik kullanımları dikkat çekmektedir (Saini ve ark, 2020).

Diyet Lifi: Diyet lifi; selüloz, pektin ve lignin gibi nişasta olmayan polisakkaritler dahil olmak üzere yalnızca bitkilerde bulunan kompleks bir karbonhidrattır (Samaan, 2017).

Yapılan çalışmalarda diyet lifinin antikanserojenik, antibakteriyel, antiinflamatuar, anti-oksidatif va anti-apoptotik özellikte olduğu; kolesterolü, trigliseridleri, sistolik kan basıncını, glisemi ve insülin duyarlılığını azalttığı görülmüştür. Diyet lifinin vücut ağırlığını ve diyabeti kontrol altına almaya yardımcı olduğu; ülser, reflü, irritabl bağırsak sendromu, divertikülit, kabızlık ve hemoroid gibi gastrointestinal hastalıkların önlenmesini sağlayabileceği düşünülmektedir (Ljubicic ve ark., 2017).

Esansiyel Yăg Asitleri: İnsan vücudunda sentezlenemediklerinden dolayı diyet yoluyla dışarıdan alınması gereken esansiyel yağ asitleri kolesterol dengesinin sağlanmasında kritik öneme sahiptir. Bu yağ asitleri; trans yağ ve kolesterolden farklı olarak HDL oranını artırırken, LDL oranını düşürerek klinik etki sergilemektedirler (Guiné ve ark., 2009).

Özelllikle uzun zincirli omega-3 yağ asitlerinin antiinflamatuar, hipolipidemik, antitrombik ve antiaritmik etkileri koroner kalp hastalığ 1 ve romatoid artrit gibi kronik hastalıkların önlenmesi ve tedavisinde uzun yıllardır kullanıldığı bilinmektedir (Lange 2020).

Flavonoidler: Flavonol, flavan-3-ol (proantosiyanidinler dahil), flavon, flavanon, antosiyanin ve izoflavon olmak üzere 6 farklı kategoriyi kapsayan flavonoidler besin takviyesi olarak en yaygın kullanılan fonksiyonel bileşenlerden bir tanesidir. Flavonoidlerin anti-hiperglisemik, antikanser ve karaciğeri koruyucu etkilerinin kantlanması, besin takviyesi olarak kullanılmalarını teşvik eden başlıca pozitif unsurlardır. Ayrıca kan basıncını düzenlediği de bildirilmiştir (Quiñones ve ark., 2011; Zhu ve ark., 2020; Bondonno ve ark., 2020).

İzotiyosiyanatlar: Brokoli, karnabahar, lahana, Brüksel lahanası ve diğer turpgillerde bulunan fitokimyasallardır (Guiné ve ark., 2009). Yapılan çalışmalarda izotiyosiyanatların antikanserojenik özellikte olduğu (Esfandiari ve ark., 2017), meme kanseri hücrelerinin çoğalmasını engellediği (Pawlik, 2017), akciğer kanseri büyümesini azalttığı (Tsai ve ark. 2019), kolorektal kanserinde antitümör etki gösterdiği bildirilmiştir (Gupta ve ark., 2019).

Fenolik Asitler: Genellikle yüksek antioksidan kapasitesine sahip olan doğal bitki özleri olarak bilinirler. Birçok fonksiyonel içeceğin formülasyonunda atletik performansı artırıcı, sindirimi hızlandırıcı vb. etkileriyle kullanılan fenolik asitlerin 
kardiyovasküler ve diyabetik risk faktörlerinin tedavisinde başarıyla kullanıldığı bildirilmiştir (Das, 2019).

Prebiyotikler: ISAPP (The International Scientific Association for Probiotics and Prebiotics - Uluslararas1 Bilimsel Probiyotik ve Prebiyotik Birliği) tarafından 2016'da gerçekleştirilen panelde prebiyotik tanımı "Konak mikroorganizma tarafından seçici olarak kullanılan, sağlığa faydalı substrat" olarak güncellenmiştir. Rapor edilen olumlu sağlık etkileri arasında bağışıklığı kuvvetlendirici, kan değerlerini düzenleyici, kemik ve zihinsel sağlığını destekleyici fonksiyonları dikkat çekicidir (Gibson ve ark., 2017). Bununla birlikte hindiba, pırasa, soğan, muz, enginar, sarımsak ve kuşkonmaz gibi meyve ve sebzelerin prebiyotik içermesine rağmen, bağırsak mikroflorasında önemli etki sergilemedikleri bildirilmiştir (Ashwini ve ark., 2019).

Probiyotikler: ISAPP (2013)'e göre probiyotikler “yeterli miktarlarda uygulandığında konakçıya sağlık yararı sağlayan mikroorganizmalar" olarak tanımlanmaktadır. İmmünolojik güçlendirme, LDL kolesterol düzeyini indirgeme, hücrelerde onarım mekanizmalarını uyarma ve dengelenmiş bağırsak ve solunum mikroflorasının oluşturulmasına katkı sağlama gibi regülatif yönleriyle öne çıkan probiyotikler, besin takviyeleri pazarında en büyük dilime sahiptir (Nair ve ark., 2017).

Fitoöstrojenler: Yapısal ve fonksiyonel olarak östrojen benzeri aktivite sergileyen fitoöstrojenler, başta soya fasulyesi olmak üzere, keten tohumu ve tam buğday tanesinde dikkate değer miktarda yer almaktadır. Özellikle prostat ve meme kanserinin engellenmesinde ve tedavisinde, osteoporoz-menopoz semptomlarının minumuma indirgenmesinde fitoöstrojenlerin biyolojik aktiviteleri öne çıkmaktadır (Sandhu ve ark., 2020; Yuan ve ark., 2019).

\section{Fonksiyonel Gıda Bileșenlerinin Tespit Edilmesinde Kullanılan Enstrümental Analiz Teknikleri}

Geleneksel kimyasal analiz yöntemleri; gıda bileşenleri tespiti için ön hazırlık işlemleri gerektirmesi sebebiyle yoğun emeğin harcandığı zaman alıcı işlemler basamaklarından oluşmaktadır (Lee ve ark., 2013). Modern analitik kimya ise; genellikle az miktarda örneğin yeterli olduğu ve farklı cihazların kullanıldı̆̆ Kalitatif analizde mevcut bir veya birden fazla kimyasal türün tanımlaması yapılırken, kantitatif analizde mevcut kimyasal türün net miktarı belirlenmektedir.

Enstrümental yöntemler; spektroskopik, kromatografik elektroforetik, kütle spektrometresi ve hibrit teknikler olarak sinıflandirılmaktadır (Otles ve Ozyurt, 2015).

\subsection{Spektroskopik Yöntemler}

Spektroskopik yöntemler, tarım ürünlerinde özellikle de gıdaların kalitesini değerlendirmede birçok ilke imza atmış başarılı tekniklerden birisidir. Bu yöntemler gıda bileşenlerinin analizi için oldukça caziptir. Çünkü genellikle minimum düzeyde numune hazırlığı gerektirir (bazen de hazırlık gerektirmez), hızlı ve çevrimiçi analiz sağlar ve tek bir numune üzerinde birden fazla test yürütme potansiyeline sahiptirler (Nawrocka ve Lamorska, 2013).

\subsubsection{Raman Spektroskopisi}

Raman spektroskopisi; çeşitli gıda bileşenlerinin ölçülmesinde kullanılan titreşimli bir spektroskopi yöntemidir. Çok yönlü uygulama alanına sahip olması ve yöntemin hızlı olması nedeniyle ilgi çekmektedir (Argyri ve ark., 2013; Lee ve ark, 2013).

$\mathrm{Bu}$ yöntem kullanılarak, domateslerde bulunan karotenoidlerin kantitatif analizinde uygun dalga boyunun belirlenmesi üzerine bir çalışma yapılmıştır. Farklı dalga boylarında $(532 \mathrm{~nm}, 785 \mathrm{~nm}$ ve $1064 \mathrm{~nm})$ yapılan analizler neticesinde, $532 \mathrm{~nm}$ dalga boyunun kalitatif analizde kullanılabileceği; bu dalga boyuyla domateste likopen, $\beta$-karoten ve lutein vb. karotenoid bileşenlerin varlığının tespit edilebileceği, kantitatif analiz için de en uygun dalga boyunun $785 \mathrm{~nm}$ olduğu gözlenmiştir (Hara ve ark., 2018).

Raman spektroskopisi kullanılarak soya fasulyesinin ham protein ve yağ içeriklerinin saptanabildiği bir başka çalışmada bildirilmiştir (Lee ve ark., 2013).

\subsubsection{Floresans Spektroskopisi}

Floresans spektroskopisi, teknolojik süreç ve depolama sonrası gida ürünlerinde meydana gelen değişiklikleri ve bunların gıda kalitesi üzerine etkilerini belirlemek için kullanılır. Bu yöntemde kimyasal reaktifler kullanılmadan gıdaların çeşitli özellikleri (fonksiyonel bileşen, kompozisyon, besin bileşeni gibi) belirlenebilir (Karoui ve Blecker, 2010).

Kırmızı ve beyaz et ve et ürünleri protein, çoklu doymamış yağ asitleri, vitaminler ve minerallerce zengin bir kompozisyona sahiptir. Ancak canlı dokuda ölüm sonrası gerçekleşen mikrobiyal artış, oksidasyon ve enzimatik otoliz sonucunda kırmızı ve beyaz etin depolama sırasındaki kalitesi hızla düşmektedir. Bu sebeple bu ürünlerin kalitesini korumak ve gıda güvenliğini sağlamak için hızlı analiz yöntemleri elzemdir.

Literatürün ayrıntılı olarak incelendiği bir çalışmada; balık ve diğer deniz ürünlerinin kalite ve özgünlük analizi uygulamalarında hızlı sonuç veren Floresans spektroskopisinin sıklıkla kullanıldığı, bu yöntemle lipid ve protein oksidasyonu sonucu oluşan değişikliklerin izlenerek kalitenin belirlendiği ifade edilmiştir. Aynı çalışmada, çeşitli sı̆̆ır kaslarının Floresans spektrumlarının okunması neticesinde kasların protein, yağ, kolajen ve kuru madde içeriklerine göre sınıflandırma yapılabildiği rapor edilmiştir. Floresans spektroskopisinin diğer spektroskopik yöntemlere kıyasla çok daha hassas ve hızlı bir yöntem olduğu belirtilmiştir (Hassoun ve ark., 2019).

\subsubsection{Ultraviyole Spektroskopisi}

Absorpsiyon spektroskopik metodlardan olan UV spektroskopisinde 200-400 nm dalga boyları UV bölgesini oluşturmaktadır. Kullanılan UV ışınları moleküller tarafından absorplanmakta ve daha fazla enerji kazanan elektronlar sayesinde spektrum değerleri okunabilmektedir (Chiyaril vd., 2017).

Berktaş ve Çam (2020) iğde meyvesinde gerçekleştirdikleri bir çalışmada, meyvede mevcut toplam fenolik ve flavanoid miktarlarının belirlemesinde spektrofotometreden yararlanmıştır.

Meyve ve sebzelerdeki antosiyaninleri tanımlamak ve miktarlarını belirlemek için UV spektroskopisinin sıklıkla kullanıldığ1 ve genellikle 520-540 $\mathrm{nm}$ arasında değerlerinin 
okunduğu bilgisi de literatürde yer almaktadır (Shipp ve Abdel-

Aal, 2010).

Tablo 1. Enstrümental Analiz Tekniklerinin Gruplandırılması (Otles ve Ozyurt, 2015)

\begin{tabular}{|c|c|c|c|}
\hline \multicolumn{4}{|c|}{ Enstrümental Analiz Teknikleri } \\
\hline Spektroskopi & Kromatografi & Elektroforez & $\begin{array}{c}\text { Kütle Spektrometresi ve Hibrit } \\
\text { Teknikler }\end{array}$ \\
\hline $\begin{array}{l}\text { Absorpsiyon spektroskopisi } \\
\text { (UV) }\end{array}$ & Gaz kromatografisi (GC) & $\begin{array}{c}\text { Jel } \\
\text { Elektroforez (GE) }\end{array}$ & $\begin{array}{l}\text { Gas kromatografisi-Kütle } \\
\text { spektrometresi (GC-MS) }\end{array}$ \\
\hline $\begin{array}{c}\text { Kızılötesi spektroskopi (IR, NIR, } \\
\text { MIR, FT-IR) }\end{array}$ & Siv1 kromatografisi (LC) & Kapilar elektroforez (CE) & Siv1 kromatografisi (LC-MS) \\
\hline Atomik spektroskopi (AS) & $\begin{array}{l}\text { Süperkritik akışkan } \\
\text { kromatografisi (SFC) }\end{array}$ & & $\begin{array}{l}\text { Ultra yüksek performanslı LC- Kütle } \\
\text { spektrometresi (UHPLC-MS/MS) }\end{array}$ \\
\hline $\begin{array}{l}\text { Nükleer manyetik rezonans } \\
\text { (NMR) spektroskopisi }\end{array}$ & Kağıt kromatografisi & & Tandem kütle spektrometresi (MS/MS) \\
\hline \multirow[t]{7}{*}{ X-Ray spektroskopisi } & $\begin{array}{c}\text { İnce tabaka } \\
\text { kromatografisi (TLC) }\end{array}$ & & $\begin{array}{l}\text { Elektrosprey iyonizasyon-Kütle } \\
\text { spektrometresi (ESI-MS) }\end{array}$ \\
\hline & & & $\begin{array}{l}\text { Atmosferik basınçlı kimyasal } \\
\text { iyonizasyon (APCI) }\end{array}$ \\
\hline & & & $\begin{array}{l}\text { Atmosferik basınçlı fotoiyonizasyon } \\
\text { (APPI-LC-MS) }\end{array}$ \\
\hline & & & $\begin{array}{l}\text { Matris destekli lazer desorpsiyon } \\
\text { iyonizasyonu (MALDI) }\end{array}$ \\
\hline & & & $\begin{array}{c}\text { Desorpsiyon elektrosprey iyonizasyon } \\
\text { (DESI) }\end{array}$ \\
\hline & & & $\begin{array}{l}\text { Desorpsiyon atmosferik basıç̧lı } \\
\text { kimyasal iyonizasyon (DAPCI) }\end{array}$ \\
\hline & & & Gerçek zamanlı direkt analiz (DART) \\
\hline
\end{tabular}

\subsubsection{FTIR-ATR Spektroskopisi}

Kimyasal analitik metodlarından biri olan ve Fourier dönüşüm yöntemi olarak da adlandırılan FTIR ile 1şığın infrared yoğunluğuna karşı dalga boyu ölçülmektedir. $\mathrm{Bu}$ sistemde kullanılan dalga boyu aralıkları Tablo 2'de gösterildiği gibidir (Kılıç ve Karahan, 2010).
Tablo 2. Elektromanyetik Spektrum Kızıl Ötesi Bölgeleri (Kılıç ve Karahan, 2010)

\begin{tabular}{cc}
\hline Kızlötesi Bölge Türü & Dalga Boyu $\left(\mathbf{c m}^{-\mathbf{1}}\right)$ \\
\hline Yakın (NIR) & $4000-14000$ \\
Orta (MIR) & $400-4000$ \\
Uzak (FIR) & $4-400$
\end{tabular}


FTIR-ATR yöntemi, gıda araştırmalarında kalitatif ve kantitatif analizler için kullanılmaktadır. Gıdalarda kalite, güvenilirlik ve izlenebilirliğin sağlanması için bileşiklerin hızlı değerlendirmesine olanak sağlar. Gıda sınıflandırması, ayrıştırma ve kimlik doğrulamasının yanı sıra kontaminantların ve tağşişin izlenmesindeki uygulamalar için kızılötesi spektroskopi skalası genişletilebilmektedir.

$\mathrm{Bu}$ yöntem ile et ve et ürünlerinde yağ asidi içeriğinin belirlenmesi çalışılmıştır. Doymuş yağ asitleri ile tekli ve çoklu doymamış yağ asitlerinin oranı saptanabilmiştir (Lucarini ve ark., 2018).

Yine aynı yöntemin kullanıldığı bir diğer çalışmada; sorgum ununun major kimyasal bileşenlerinin karakterize edilmesi amaçlanmıştır. FTIR-ATR yöntemi ile ürün içerisindeki temel bileşenin nişasta olduğu ve daha az miktarda protein, lipid ve fenolik asitler içerdiği tespit edilmiştir. Özellikle protein içeriklerini belirlemede hızlı ve hassas bir yöntem olduğu ortaya koyulmuştur (Lin ve ark., 2021).

\subsection{Kromatografik Yöntemler}

Kromatografi; bir numunedeki bir veya birkaç bileşenin ölçülmesinden ziyade genellikle seçici dedektörleri ile analitteki tüm bileşenleri ayırma, tespit etme, kimlik belirleme ve kantitatif olarak ifade etmede üstün avantajlar sağlayan tekniklerden bir tanesidir. Mikrodan makroya kadar değişen ölçüm aralıklarında gerçekleştirilen kantitatif analizlerde hassas, seçici ve çok yönlü tanımlama sağlaması nedeniyle laboratuvarlarda oldukça yaygın kullanılan yöntemlerden biri haline gelmiştir (Wixom vd., 2011).

\subsubsection{Gaz Kromatografisi}

Gıda laboratuvarlarında kullanılan temel tekniklerden biri olan gaz kromatografisi (GC) ile birçok gida bileşeni analiz edilebilmektedir. GC'nin bu kadar popüler olmasının nedeni; çok yüksek seçicilik ve çözünürlüğe sahip olması ile yüksek doğruluk ve hassasiyette sonuç vermesine dayanmaktadır (Feng vd., 2019).

Et ürünlerinde yağ asitleri tayininde genellikle iki fazlı metilasyon yöntemleri kullanılmaktadır. Yapılan bir çalışmada et ürünlerinde yağ asitleri analizi için tek aşamalı transmetilasyon ve hızlı GC yöntemi denenerek prosedür işlemi kolaylaştırılarak analiz süresi 1 saatten 10 dakikaya kadar indirilebilmiştir (PerezPalacios ve ark., 2021).

Kore'de yenilebilir mantar ürünlerinin sterol ve yă kompozisyonları tespiti için GC'den yararlanılmıştır (Saini ve ark., 2021).

Güney Afrika'da yetişen bazı yerli bitkilerin antioksidan kapasitesi, toplam flavonoid ve toplam fenolik içerikleri de GC kullanımıyla tespit edilebilmiştir (da Silva ve ark., 2019).

\subsubsection{Sivi Kromatografisi}

Cortés-Herrera vd. (2018) yaptıkları bir derleme çalışmasında yem ve gıdalarda yaygın olarak bulunan majör bazı bileşenlerin tespit edilmesinde sivi kromatografisi tekniğini değerlendirmişlerdir. Çalışmada özellikle, örnek hazırlama ve kromatografik analiz işlemleri sırasında karşılaşılan ortak engellere ve farklılıklara odaklanılmıştır. Derleme kendi içinde üç kısma ayrılmıştır. İlk kısımda besin zincirinin başlangıcı olarak yem analizlerine yer verilmiş, ikinci kısımda gıda zincirinin sonu olarak tüketime sunulacak üründe analizlere değinilmiş ve son kısımda ise laboratuvarda gerçekleştirilen analiz sonuçları e-ISSN: 2148-2683 derlenmiştir. Çalışma neticesinde polifonellor, kapsaisinoidler, karotenoidler, teobromin, kafein, kolesterol, amino asit, karbonhidrat, şeker, organik asit, suda ve yağda çözünen vitaminlerin sivı kromatografisiyle detaylı olarak analiz edilebildiği, tekniğin yem ve gıda analizlerinde güçlü ve çok yönlü olduğu fakat analiz öncesinde numunede detaylı ve titiz ekstraksiyon / saflaştırma basamaklarına ihtiyaç duyulabildiği bildirilmiştir.

\subsubsection{Yüksek Performanslı Sıvi Kromatografisi (High Performance Liquid Chromatography-HPLC)}

Karadeniz bölgesinde üretilen Ormangülü balında mevcut 17 adet fenolik bileşenin kalitatif ve kantitatif analizleri RP-HPLCDAD (ters fazlı ve diot taramalı dedektörlü yüksek performanslı sıvı kromatografisi) kullanılarak yapılmıştır (Şahin ve ark., 2017).

Acı biberlerin (Jalapeño, Scotch Bonnet ve Bhut Jolokia) sulu ekstraktlarında bulunan fonksiyonel bileşenlerin tespiti için yapılan bir diğer çalışmada ise, acı biberlerde kapsaisinoid dışında suda çözünür keskin olmayan fonksiyonel bileşenlerin izolasyonu ve karakterizasyonu HPLC ile sağlanmıştır (Liu ve Nair, 2010).

Kudret nar1 meyvesinde (Momordica charantia) bulunan charantin, stigmasterol glukozit (STG) ve $\beta$-sitosterol glukozit (BSG) adlı iki bileşenin karışımından oluşan steroidal bir saponindir ve insüline karşı anti-diyabetik etki sergilediği bilinmektedir. Yapılan bir çalışmada; kurutulmuş kudret narı meyvesinde charantin bileşenlerinin (STG ve BSG) kalitatif ve kantitatif olarak tespit edilmesi için kromatografik teknikler kullanılmıştır. Ters fazlı HPLC-DAD yönteminin charantin bileşenlerinin varlığının ortaya koyulmasında ve bireysel olarak belirlenmesinde hassas ve başarılı sonuçlar verdiği bildirilmiştir (Desai ve ark., 2021).

Fruktus amomi meyvesiyle yapılan bir çalışmada ise; meyvede bulunan östrojen-aktif bileşiklerin analizi ve belirlenmesi için yüksek hızlı ters akım kromatografisi (High Speed Countercurrent Chromatography-HSCCC) ve HLPC kombinasyonu oluşturulmuştur. Meyvede bulunan östrojen-aktif bileşenlerden Amomum longiligulare tohumlarının ayrımı HSCCC ile gerçekleştirildiğinde, HPLC'ye kıyasla daha fazla randıman alındığı görülmüştür. Sonuçlara göre meyvenin 3 gram etanolik ekstraktından 8-138 miligram miktarında ve \% 94.3 99.8 saflıkta 17 farklı bileşik elde edilmiştir. Bileşiklerin kimyasal yapıları ESI-MS ve NMR spektrumları ile belirlenmiş olup sekiz adet östrojen-aktif bileşen olduğu görülmüştür. Meyvenin, östrojen aktivitesine sahip diarilheptanoidler bakımından zengin bir besin kaynağı olduğu, biyoaktif bileşenlerin analizi için HSCCC ve HPLC kombinasyonunun uygulanabilir olduğu bildirilmiştir (Ying ve ark., 2014).

\subsubsection{Yüksek Performansl Ince Tabaka Kromatografisi (High Performance Thin-Layer Chromatography- HPTLC)}

Bitki özleri gibi oldukça karmaşık numunelerin taranması için sıklıkla kullanılan yüksek verimli ve güvenilir bir ayırma tekniği olarak tasarlanmıştır. Tek bir kromatografik plakanın birçok numunede benzerliğin daha iyi tanınmasını sağlamak için aynı laboratuvar koşullarında paralel çalışma kapasitesi bulunmaktadır. Ayrıca; enzim uygulamalarından önce kolaylıkla çıkarılabilen mobil faz ile enzimatik biyoanalizlerle uyumlu olup böylelikle etkinliklerini artırabilmektedir. Numune hazırlığ yapılmadan ya da minimal düzeyde yapılan hazırlık işlemi sonrası 
ekstraktlar doğrudan plakaya uygulanabilmektedir. Böylece; numune bileşenlerinin çoğu mümkün olduğunca korunmaktadır (Agatonovic-Kustrin ve ark., 2020).

\subsection{Kütle Spektrometresi}

Kütle spektrometresine dayanan analiz yöntemleri kalitatif ve kantitatif metodların her ikisinde de sonuç vermektedir. Kütle spektrometresinin (Mass spectrometry-MS) kullanımıyla moleküler ağırlık saptanması sonucu hızla ve güvenli bir şekilde analizler gerçekleştirilebilmektedir.

Moleküler ağırlık belirlendikten sonra kromatografik teknik veya güvenilir başka bir yöntem ile birlikte kullanıldı̆̆ında hedeflenen bileşiklerin tanımlanması sağlanmaktadır. Örneklerin spesifik özelliklerinin tespit edilmesinde farklı MS çeşitleri kullanılabilmekte ve ayrıca; daha fazla seçicilik ve yüksek çözünürlük özellikleri olması nedeni ile bileşen miktarı da hesaplanabilmektedir (Lee, 2012).

\subsubsection{Yüksek Çözünürlüklü Kütle Spektrometresi (High- Resolution Mass Spectrometry-HRMS)}

Yüksek çözünürlüklü kütle spektrometresi (HRMS), bileşenlerin molekül kütlesi, temel kompozisyonu ve ayrıntılı moleküler yapısı ile ilgili olarak daha kapsamlı bilgi sağlama konusundaki üstün yetenekleri nedeniyle dikkat çekmektedir. HRMS'nin klasik bir MS'e göre birçok avantajı bulunmaktadır. $\mathrm{Bu}$ yöntem; izobarik bileşiklerin tanımlanması, daha az ön hazırlık işlemi gerektirmesi nedeniyle hızlı bir teknik olması, tek bir işlemle hedeflenmemiş analizler de dahil birçok bileşenin saptanabilmesi, tarama spektrumların sonraki aşamalar için saklanabilmesi ve kullanılabilmesi nedeniyle tercih edilmektedir (Lucci ve ark, 2017).

\subsection{Kombine Sistemler}

Enstrümental analizlerde farklı cihazların kombine edilerek bir arada kullanılması mümkündür. Lactobacillus plantarum ATCC14917 ile fermente edilen elma suyunda antioksidan kapasite değişimi izlenmiştir. Fermente elma suyunun bileşimi LC-MS/MS (S1v1 Kromatografi-Kütle Spektrometresi/Kütle Spektrometresi) kombine sistemiyle karakterize edilmiştir. Fermantasyon sonrası toplam fenolik ve flavonoid içeriğinin düştüğü, antioksidan kapasitesinin önemli bir oranda arttığı, serbest radikallerin etkisiz hale dönüştürüldüğü gözlenmiştir. Laktik asit bakterilerinin elma fermantasyonunda kullanılabileceği, mevcut polifenollerin biyoyararlanımını artırılabileceği ve bu elma suyunun serbest radikallerin neden olduğun hastalıkların önlenmesinde fonksiyonel bir gida olarak tüketilebileceği de bildirilmiştirır (Li vd., 2018).

Tropikal ve kurak iklimlerde yetişen Moringa türleri; besleyici, tıbbi ve endüstriyel faydaları olan çok amaçlı bitkilerdir. Makita vd. (2016) Moringa oleifera ve Moringa ovalifolia'nın flavonoid içeriklerini ultra yüksek performanslı sıvı kromatografisi (UHPLC) ve quadrupol uçuş zamanlı kütle spektrometresi (qTOF-MS) tekniklerini kombine ederek analiz etmişlerdir. Sonuçlara göre; iki türün aralarında en az 17 farklı flavonoid bileşiği içerdiği görülmüş olup, içerikleri hakkında detaylı bir inceleme yapılmadığı bildirilmiştir.

Çin'de ticari kırmızı şarapların kalitesini belirlemek için Yüksek Performanslı Siv1 Kromatografisi ve elektrosprey iyonizasyon kütle spektrometresi (ESI-MS) yöntemleri birlikte uygulanmıştır. Analiz edilen şaraplarda 18 adedi antioksidan olmak üzere toplamda 25 bileşen tanımlanmış ve değerlendirilmiştir. Örneklerde bulunan baskın ve karakteristik antioksidanlar belirlenmiştir. Sonuçlara göre ekili üzüm çeşidi, üretim alanı, mahzen dönemi gibi faktörlerin antioksidan etki gücüne etkileri tartışılmıştır. Araştırmacılar bu yöntemle kırmızı şarabın kimyasal özelliklerinin ve antioksidan gücünün ilk defa analiz edildiğini ve değerlendirildiğini, yöntemin yüksek antioksidan içeriğini sahip ürünlerde karakterizasyon işlemi için kullanılabileceğini ifade etmişlerdir (Yu ve ark., 2014).

Anti-spazmodik, diüretik, antiseptik, yatıştırıcı, analjezik, boğaz ağrısını hafifletici ve bağırsak parazitleri elimine edici pozitif sağlık etkileriyle bilinen altın çilek (Physalis peruviana L.) meyvesinin işlenmesi sırasında oluşan atıkların, fenolik asit, flavonoid, terpenoid, fitosterol ve fitol türevlerince (E vitamini) zengin olduğunu ortaya koymak amacıyla bir çalışma yürütülmüştür. $\mathrm{Bu}$ kapsamda, meyve atıklarının kapsamlı karakterizasyonu için elektrosprey iyonizasyon kütle spektometresi (ESI) ile UPLC-ESI-q-TOF-MS / MS yöntemi kombine edilerek kullanılmıştır. Çalışmanın ikinci aşamasında ise; yan ürün ekstraktından biyoaktif bileşiklerin tanımlanması gerçekleştirilmiş; fenolik bileşikler çoğunlukta olmak üzere, çeşitli biyolojik aktivitelere sahip birkaç vitanolid (C28izoprenoidler) ve toplam 56 fitokimyasal sükroz esterleri tanımlanmıştır. İzobarik vitanolit tip bileşenler de iyon spektrumları tarafindan ESI(+) ve ESI(-) modlarında MS/MS kullanılarak sınıflandırılmıştır. ESI(-) modunda vitanolitlerin yapısal analizine MS/MS katkı sağlamıştır. (GC-qTOF-MS) tekniği de altın çilekte var olan fitosteroller ve tokoferollerin karakterize edilmesinde özgün sonuçlar ortaya koymuştur (Ballesteros-Vivas, 2019).

\section{Sonuc}

Gıda ürünlerinin tarladan soframıza uzanan yolculuğundaki süreçte ürünlerde bir takım değişiklikler yaşanabilmektedir. Çünkü; gıda ürünü çeşitli grupların bir araya gelmesiyle oluşan (protein, karbonhidrat, yă̆, vitamin, mineral gibi) oldukça kompleks bir yap1 olup beraberinde kontaminantlar ve kalıntılar da barındırabilmektedir. Ürün grubu, ekili olduğu alan, tarlada yapılan ilaçlamalar, hasat işlemleri, fabrikada uygulanan üretim prosesleri, depolama gibi aşamalardan geçen gıdaların bileşiminde meydana gelebilecek değişimler kaçınılmazdır. Hayvansal gıdalarda da; hayvanın yetiştiği coğrafya, yaşı, cinsi, beslenmesinde kullanılan yem de sahip olduğu özelliklerini etkilemektedir. Ayrıca; evlerimizde besinlere uygulanan son tüketim öncesi ön hazırlık işlemleri (muhafaza, yıkama, pişirme gibi) de yine gıdaların mevcut olduğu özelliklerde değişimlere yol açabilmektedir. Yapılan literatür taraması sonucu; enstrümental analiz tekniklerinin fonksiyonel gıda bileşenlerinin hızlı ve hassas biçimde tespit edilmesinde, başarıyla ve güvenle kullanılabildiği görülmüştür.

Biyoaktif bileşen içeren gıdaların sunmuş olduğu sağlık yararlarına ek olarak, toksisite testlerinin de yapılmasına ve olası risklerinin ortaya koyulmasına ihtiyaç duyulmaktadır. Her bir fonksiyonel bileşenin ayrı ayrı toksisite testlerine tabi tutulmasında ve diğer gida bileşenleriyle etkileşimlerinin irdelenmesinde, kombine enstrümental analiz tekniklerinin özgün ve dikkat çekici sonuçlar ortaya koyacağı düşünülmektedir.

\section{Kaynakça}

Acton, Q. A. Ed., (2013). Silicones-Advances in Research and Application, Atlanta: Scholarly Editions. 
Agatonovic-Kustrin, S., Doyle, E., Gegechkori, V. \& Morton, D. W. (2020). High-performance thin-layer chromatography linked with (bio) assays and FTIR-ATR spectroscopy as a method for discovery and quantification of bioactive components in native Australian plants. J. Pharm. Biomed. Anal., 184(2), 113208, doi: 10.1016/j.jpba.2020.113208.

Argyri, A. A., Jarvis, R. M., Wedge, D., Xu, Y., Panagou, E. Z., Goodacre, R. \& Nychas, G. J. E. (2013). A comparison of Raman and FT-IR spectroscopy for the prediction of meat spoilage. Food Control, 29(2), 461-470, doi: 10.1016/j.foodcont.2012.05.040.

Ashwini, A., Ramya, H. N., Ramkumar, C., Reddy, K. R., Kulvarni, R. V., Abinaya, V., Naveen, S. \& Raghu, A. V. (2019). Reactive mechanism and the applications of bioactive prebiotics for human health: Review. J. Microbiol. Meth., 159, 128-137, doi: 10.1016/j.mimet.2019.02.019.

Ballesteros-Vivas, D., Álvarez-Rivera, G., Ibánez, E., ParadaAlfonso, F. \& Cifuentes, A. (2019). A multi-analytical platform based on pressurized-liquid extraction, in vitro assays and liquid chromatography/gas chromatography coupled to high resolution mass spectrometry for food byproducts valorisation. Part 2: Characterization of bioactive compounds from goldenberry (Physalis peruviana L.) calyx extracts using hyphenated techniques. J. Chromatogr. A, 1584, 144-154, doi: 10.1016/j.chroma.2018.11.054.

Berktaş, S. \& Çam, M. (2020). İğde (Elaeagnus angustifolia L.) meyve ve yapraklarının antioksidan ve antidiyabetik özellikleri. Akademik Glda, 18(3), 270-278, doi: 10.24323/akademik-gida.818125.

Bondonno, N. P., Lewis, J. R., Blekkenhorst, L. C., Bondonno, C. P., Shin, J. H. C., Croft, K. D., Woodman, R. J., Wong, G., Lim, W. H., Gopinath, B., Flood, V. M., Russell, J., Mitchell, P. \& Hodgson, J. M. (2020). Association of flavonoids and flavonoid-rich foods with all-cause mortality: The Blue Mountains Eye Study. Clin. Nutr., 39(1), 141-150, doi: 10.1016/j.clnu.2019.01.004.

Bruulsema, T.W. (2020). Functional Food Components: A Role for Mineral Nutrients?, 21.12.2020 tarihinde Better Crops sitesi

http://www.ipni.net/publication/bettercrops.nsf/0/00D32CD 0F2B5528F852579800081FD1B/\$FILE/Better\%20Crops\% 202000-2\%20p04.pdf adresinden alınd1.

Chirayil, C. J., Abraham, J., Mishra, R. K., George, S. C. \& Thomas, S. (2017). Chapter 1 - Instrumental Techniques For The Characterization of Nanoparticles, In S. Thomas, R. Thomas, A. K. Zachariah \& R. Mishra (Eds.), Thermal and Rheological Measurement Techniques for Nanomaterials Characterization (pp. 1-36), Elsevier, doi: 10.1016/B978-0323-46139-9.00001-3.

Cortés-Herrera, C., Artavia, G., Leiva, A. \& Granados-Chinchilla, F. (2018). Liquid chromatography analysis of common nutritional components, in feed and food. Foods, 8(1), 1, doi: 10.3390/foods 8010001 .

Das, A. B., Goud, V. V. \& Das, C. (2019). Phenolic Compounds of Functional Ingredients in Beverages. Value-Added Ingredients and Enrichments of Beverages, In A. M. Grumezescu \& A. M. Holban (Eds.), ser. The Science of Beverages vol. 14 (pp. 285-323), Woodhead Publishing.

Deepak (2015). What are the benefits offered by Modern Analytical Instrumental methods over non-instrumental methods?, 21.12.2020 tarihinde lab-training.com sitesi https://lab-training.com/2015/03/10/what-are-the-benefits- offered-by-modern-analytical-instrumental-methods-overnon-instrumental-methods/ adresinden alınd1.

Desai, S., Tatke, P., Mane, T. \& Gabhe, S. (2021). Isolation, characterization and quantitative HPLC-DAD analysis of components of charantin from fruits of Momordica charantia. Food Chem., 345, 128717, doi: 10.1016/j.foodchem.2020.128717.

Esfandiari, A., Saei, A., McKenzie, M. J., Matich, A. J., Babalar, M. \& Hunter, D. A. (2017). Preferentially enhancing anticancer isothiocyanates over glucosinolates in broccoli sprouts: How $\mathrm{NaCl}$ and salicylic acid affect their formation. Plant Physiol. Biochem., 115, 343-353, doi: 10.1016/j.plaphy.2017.04.003.

Feng, T., Sun, M., Song, S., Zhuang, H. \& Yao, L. (2019). Gas Chromatography for Food Quality Evaluation. In J. Zhong \& X. Wang (Eds.), Evaluation Technologies for Food Quality (pp. 219-265), Woodhead Publishing.

Functional Food Center. Definition of functional food. 21.12.2020 tarihinde Functional Food Center Inc. sitesi https://www.functionalfoodscenter.net/ adresinden alınd1.

Gibson, G. R., Hutkins, R., Sanders, M. E., Prescott, S. L., Reimer, R. A., Salminen, S. J., Scott, K., Stanton, C., Swanson, K. S., Cani, P. D., Verbeke, K. \& Reid, G. (2017). The International Scientific Association for Probiotics and Prebiotics (ISAPP) consensus statement on the definition and scope of prebiotics. Nat. Rev. Gastroenterol. Hepatol., 14, 491-502, doi: 10.1038/nrgastro.2017.75.

Guiné, R., Lima M. J. \& Barroca, M. J. (2009). Role and health benefits of different functional food components. Revista Millenium, 37(14).

Gupta, R., Bhatt, L. K. \& Momin, M. (2019). Potent antitumor activity of Laccaic acid and Phenethyl isothiocyanate combination in colorectal cancer via dual inhibition of DNA methyltransferase-1 and Histone deacetylase-1. Toxicol. Appl. Pharmacol., 377, 114631, doi: 10.1016/j.taap.2019.114631.

Hara, R., Ishigaki, M., Kitahama, Y., Ozaki, Y. \& Genkawa, T. (2018). Excitation wavelength selection for quantitative analysis of carotenoids in tomatoes using Raman spectroscopy. Food Chem., 258, 308-313, doi: 10.1016/j.foodchem.2018.03.089.

Hassoun, A., Sahar, A., Lakhal, L. \& Aït-Kaddour, A. (2019). Fluorescence spectroscopy as a rapid and non-destructive method for monitoring quality and authenticity of fish and meat products: Impact of different preservation conditions. LWT - Food Sci. Technol., 103, 279-292, doi: 10.1016/j.lwt.2019.01.021.

Karoui, R. \& Blecker, C. (2010). Fluorescence spectroscopy measurement for quality assessment of food systems-a review. Food Bioproc. Tech., 4, 364-386, doi: 10.1007/s11947-010-0370-0.

Kılıç, G. B. \& Karahan, A. G. (2010). Fourier dönüşümlü kızılötesi (FTIR) spektroskopisi ve laktik asit bakterilerinin tanısinda kullanılmasi. Glda, 35(6), 445-452.

Lange, K. W. (2020). Omega-3 fatty acids and mental health. Global Health Journal, 4(1), 18-30, doi: 10.1016/j.glohj.2020.01.004.

Lee, H., Cho, B. K., Kim, M. S., Lee, W. H., Tewari, J., Bae, H., Sohne, S. I. \& Chif, H. Y. (2013). Prediction of crude protein and oil content of soybeans using Raman spectroscopy. Sensor. Actuat. B-Chem., 185, 694-700, doi: 10.1016/j.snb.2013.04.103. 
Lee, M. S. (Ed.) (2012). Mass Spectrometry Handbook, Hoboken: John Wiley \& Sons, Inc.

Lin, H., Bean, S. R., Tilley, M., Peiris, K. H. S. \& Brabec, D. (2021). Qualitative and quantitative analysis of sorghum grain composition including protein and tannins using ATRFTIR spectroscopy. Food Anal Methods, 14(2), 268-279, doi: 10.1007/s12161-020-01874-5.

Liu, Y. \& Nair, M. G. (2010). Non-pungent functional food components in the water extracts of hot peppers. Food Chem., 122(3), 731-736, doi: 10.1016/J.FOODCHEM.2010.03.045.

Ljubicic, M., Saric, M. M., Rumbak, I., Baric, I. C., Komes, D. Satalic, Z. \& Guiné, R. P. F. (2017). Knowledge about dietary fibre and its health benefits: A cross-sectional survey of 2536 residents from across Croatia. Med. Hypotheses, 105, 25-31, doi: 10.1016/j.mehy.2017.06.019.

Lucarini, M., Durazzo, A., del Pulgar, S., Gabrielli, P. \& Lombardi-Boccia, G. (2018). Determination of fatty acid content in meat and meat products: The FTIRATR approach. Food Chem., 267, 223-230, doi: 10.1016/j.foodchem.2017.11.042.

Lucci, P., Saurina, J. \& Núñez, O. (2017). Trends in LC-MS and LC-HRMS analysis and characterization of polyphenols in food. Trends Anal. Chem., 88, 1-24, doi: 10.1016/j.trac.2016.12.006.

Makita, C., Chimuka, L., Steenkamp, P., Cukrowska, E. \& Madala, E. (2016). Comparative analyses of flavonoid content in Moringa oleifera and Moringa ovalifolia with the aid of UHPLC-qTOF-MS fingerprinting. S. Afr. J. Bot., 105, 116-122, doi: 10.1016/j.sajb.2015.12.007.

Nair, M. S., Amalaradjou, M. A. \& Venkitanarayanan, K. (2017). Chapter one - Antivirulence properties in combating microbial pathogenesis. Adv. Appl.Microbiol., 98, 1-29, doi: 10.1016/bs.aambs.2016.12.001.

Nawrocka, A. \& Lamorska, J. (2013). Determination of Food Quality by Using Spectroscopic Methods, In S. Grundas \& A. Stepniewski (Eds.), Advances in Agrophysical Research (pp. 347-367), Rijeka: InTech, doi: 10.5772/52722.

Otles, S. \& Hazalyurt, V. H. (2015). Instrumental Food Analysis, In P.C.K. Cheung \& B.M. Mehta (Eds.), Handbook of Food Chemistry (pp. 151-164), Berlin, Springer, doi: 10.1007/978-3-642-41609-5 18-1.

Pawlik, A., Wała, M., Hać, A., Felczykowska, A. \& HermanAntosiewicz, A. (2017). Sulforaphene, an isothiocyanate present in radish plants, inhibits proliferation of human breast cancer cells. Phytomedicine, 29, 1-10, doi: 10.1016/j.phymed.2017.03.007.

Perez-Palacios, T., Solomando, J. C., Ruiz-Carrascal, J. \& Antequera, T. (2021). Improvements in the methodology for fatty acids analysis in meat products: one-stage transmethylation and fast-GC method. Food Chem., 130995, In Press.

Quiñones, M., Sánchez, D., Muguerza, B., Miguel, M. \& Aleixandre, A. (2011). Mechanisms for antihypertensive effect of CocoanOX, a polyphenol-rich cocoa powder, in spontaneously hypertensive rats. Food Res. Int., 44(5), 12031208, doi: 10.1016/j.foodres.2010.10.032.

Saini, R. K., Keum, Y., Dagliad, M. \& Rengasamy, K. R. (2020). Dietary carotenoids in cancer chemoprevention and chemotherapy: A review of emerging evidence. Pharmacol., 157, 104830, doi: 10.1016/j.phrs.2020.104830.

Saini, R K., Rauf, A., Khalil, A. A., Eun-Young, K., Young-Soo, K., Anwar, S., Alamri, A. \& Rengasamy, K. R. R. (2021). Edible mushrooms show significant differences in sterols and fatty acid compositions. S. Afr. J. Bot., 141, 344-356, doi: 10.1016/j.sajb.2021.05.022.

Samaan, R. A. (Ed.) (2017). Dietary Fiber For The Prevention of Cardiovascular Disease: Fiber's Interaction Between Gut Microflora, Sugar Metabolism, Weight Control and Cardiovascular Health, Los Angeles: Elsevier Inc.

Sandhu, K. V., Demiray, Y. E., Yanagawa, Y. \& Stork, O. (2020). Dietary phytoestrogens modulate aggression and activity in social behavior circuits of male mice. Horm. Behav., 119, 104637, doi: 10.1016/j.yhbeh.2019.104637.

Shipp, J. \& Abdel-Aal, E.-S. M. (2010). Food applications and physiological effects of anthocyanins as functional food ingredients. Open Food Sci. J., 4, 7-22, doi: 10.2174/1874256401004010007.

Siegrist, M., Shi, J., Giusto, A. \& Hartmann, C. (2015). Worlds apart. Consumer acceptance of functional foods and beverages in Germany and China. Appetite, 92, 87-93, doi: 10.1016/j.appet.2015.05.017.

da Silva, P. G., Spricigo, P. C., Purgatto, E., de Alencar, S. M. \& Jacomino, A. P. (2019). Volatile compounds determined by SPME-GC, bioactive compounds, in vitro antioxidant capacity and physicochemical characteristics of four native fruits from South America. Plant Foods Hum. Nutr., 74(3), 358-363, doi: 10.1007/s11130-019-00745-7.

Southon, S. \& Faulks, R. (2003). Carotenoids in Food: Bioavailability and Functional Benefits, In I. Johnson \& G. Williamson (Eds.), Phytochemical Functional Food (pp. 107127), Cambridge: Woodhead Publishing Limited.

Şahin, H., Can, Z. \& Kolaylı, S. (2017). Bazı ormangülü ballarının fenolik içerik kompozisyonu. Arıcılık Araştırma Dergisi, 9(2), 40-46.

Tsai, J. Y., Tsai, S. H. \& Wu, C. C. (2019). The chemopreventive isothiocyanate sulforaphane reduces anoikis resistance and anchorage-independent growth in non-small cell human lung cancer cells. Toxicol. Appl. Pharmacol., 362(1), 116-124, doi: 10.1016/j.taap.2018.10.020.

Wixom, R. L., Gehrke, C. W., Berezkin, V. G. \& Janak, J. (2011). Chromatography - A New Discipline of Science, In R.L. Wixom \& C.W. Gehrke (Eds.), Chromatography: A Science of Discovery (pp. 1-13), New Jersey: John Wiley \& Sons, Inc., doi: 10.1002/9780470555729.ch1.

Ying, H., Liu, J. \& Du, Q. (2014). Analysis and determination of oestrogen-active compounds in fructus amomi by the combination of high-speed counter-current chromatography and high performance liquid chromatography. J. Chromatogr B Analyt. Technol. Biomed. Life Sci., 958, 36-42, doi: 10.1016/j.jchromb.2014.03.006.

Yu, H. X., Sun, L. Q. \& QI, J. (2014). The integrated quality assessment of Chinese commercial dry red wine based on a method of online HPLC-DAD-CL combined with HPLCESI-MS. Chin. J. Nat. Med., 12(7), 517-524, doi: 10.1016/S1875-5364(14)60081-9.

Yuan, G., Liu, Y., Liu, G., Wei, L., Wen, Y., Huang, S., Guo, Y., Zou, F. \& Cheng, J. (2019). Associations between semen phytoestrogens concentrations and semen quality in Chinese men. Environ. Int., 129, 136-144, doi: 10.1016/j.envint.2019.04.076.

Zhu, X., Ouyang, W., Lan, Y., Xiao, H., Tang, L., Liu, G., Feng, K., Zhang, L., Song, M. \& Cao, Y. (2020). Antihyperglycemic and liver protective effects of flavonoids from Psidium guajava L. (guava) leaf in diabetic mice. Food Biosci., 35, 100574, doi: 10.1016/j.fbio.2020.100574. 